\title{
TREND OF TYPE 2 DIABETES MELLITUS \\ DATA STUDY (2015 - 2019)
}

\author{
Luh Titi Handayani \\ Faculty of Health Science, University of Muhammadiyah Jember \\ Corresponding e-mail : luhtitihandayani@unmuhjember.ac.id
}

\begin{abstract}
BACKGROUND : Diabetes mellitus (DM) is degenerative disease and non communicable disease which need the right treatment. DM is a condition which is the blood glucose is increase above the normal or called hyperglicemia. The prevalence of DM tend to increase in Indonesia until 2030. Inadequate treatment will lead to serious complication. DM is the biggest thread for human health. Tendency to increase is correlate with change of lifestyle and urbanisation.
\end{abstract}

SUBJECT AND METHODE : This study is using reference from previous journals and publications and then analyse using decriptive analysis.

RESULTS : the results from journal description reveal that there were several factors, which is the enabiling and risk factors of DM including age, gender, obesity, lack of activity, unhealthy life style, prevention using $\mathrm{HbA1C}$ which is not optimal, not optimal medication and not making good use of existing facilities.

CONCLUSION : the treatment and prevention of diabetes mellitus are needed good collaboration from the patients itself, family and health care team including physician, nurse and dieitician.

Key words : trend of type 2 diabetes mellitus

\section{INTRODUCTION}

\section{Background}

The shifting form communicable to non communicable disease are brings up degenerative disease, and one of them is diabetes mellitus (DM). Based on the data from Perkeni (2015) from epidological perspective Indonesia has been on type 2 diabetes mellitus epideic. The tendency of increasing prevalence are due to changing of life style and urbanization. The prediction stated that $50 \%$ of people with diabetes are undiagnosed and two third who get treatment both pharmacological and non pharmacological so that they could control the blood glucose and prevent complication. One of clinical sign of diabetes mellitus is elevating blood glucose or hyperglicemia.

At 20130 the prevalence of diabetes mellitus is predicted to increase $1 \mathrm{t} 4.4 \%$ or reach to 366 millions of people and Asia are contributin to $60 \%$ from all of populations (Diagnosis and Classification of Diabetes Mellits, 2011). The data from WHO stated that in 2015 Indonesia is in the seventh place for highest prevalence in the world. The prevalence in Indonesia is tend to increase to $6.9 \%$ in 2013 from $5.7 \%$ in 2007. Basic health research (Riskesdas) 2013 stated that overweight is the trigger of diabetes mellitus and it increase to $15.4 \%$ in 2030.

Diabetes is metabolic disease characterized by hyperglicemia due to insulin secretion disorder, impaired insulin work, or both. Impairment of carbohidrate, fat and protein metabolism used 
to happen in type 1 diabetes mellitus, the forth chategory of diabetes including type 1 diabetes mellitus, type 2 diabetes mellitus, gestanional diabetes and other type diabetes mellitus (Krenel and Brukel, 2014).

\section{State of Problem}

The problem faced by Indoensia in treating diabetes mellitus is that not all of people with diabetes mellitus have acces to adequate health facillities, including availability of oral and injection drugs at primary health care and limited facilities at health care services. The limitation of health care personil's ability in treating diabetes and it complication in aall aspect of pomotive, preventive, curative and rehabilitative still became the obstacle in delivering primary jealth services.

\section{LITERATURE REVIEW}

Diabetes mellitus is a chronic disease charaterized by elevated blood glucose at $200 \mathrm{mg} / \mathrm{dl}$ for randomized blood glucose and $126 \mathrm{mg} / \mathrm{dl}$ for fasting blood glucose. Diabetes is known as silent killer because it is often nor realized by the person and when it is known the complication has occured (Ministry Of Health Indonesia Republic of Indonedia, 2014). Diabetes mellitus could attack almost all system of human body, from the skin through the heart and it could lead to complication.

The pathogenesis of hyperglicemia in type 2 diabetes mellitus is due to some disfunction of organs such as liver, pancreas and kidney.

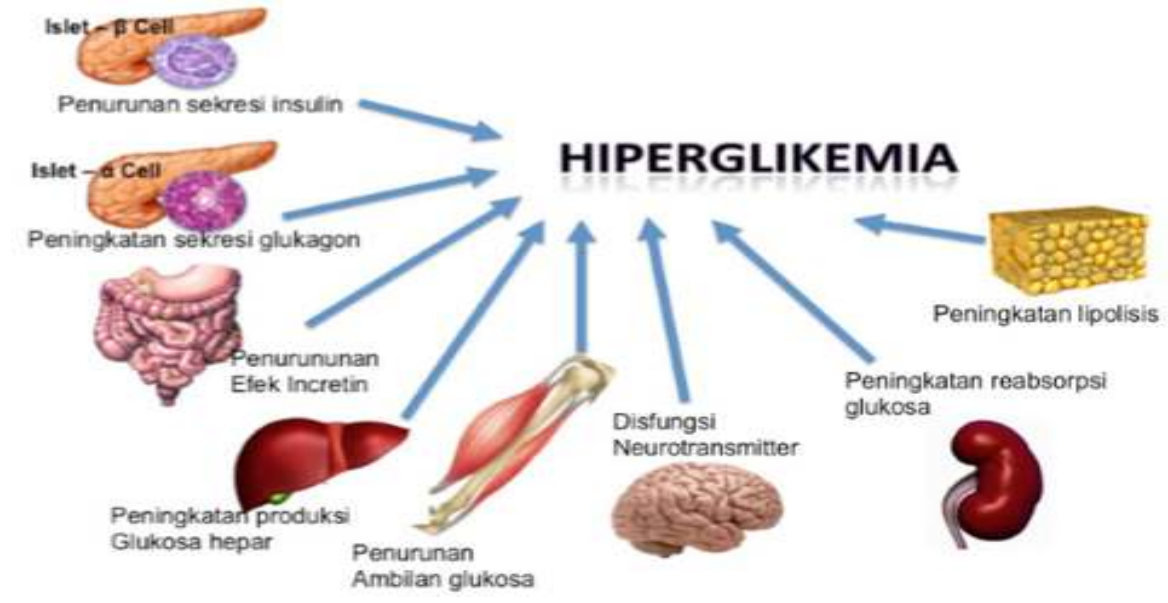

Pict 1. The pathigenesis of hyperglicemia

The diagnosis of diabetes mellitus is made based on the asessment of blood glucose taken from the vein.

Diabetes suspicion if there is a classic complaint of diabetes : polyuria, polydipsy, polyphagia and unexplained weight loss plus other complaints sich as weakness, tigling, itching, blurry eyes and pruritus in the vulva region.

The Diabaets Mellitus Diagnosis Criteria

Fasting plasma blood glucose examination $\geq 126 \mathrm{mg} / \mathrm{dl}$. Fasting is no calorie intake of at least 8 hours, or 
Plasma glucose examination $\geq 200 \mathrm{mg} / \mathrm{dl}$ after the glucose tolerance test (TTGO) with a glucose load of 75 grams, or

\section{Or}

$\mathrm{HbA} 1 \mathrm{c}$ examination $\geq 6.5$ using a standardized methode by the National Glychohaemoglobin

Standarization Program (NGSP)

Laboratory Bloods Levels for Diagnosis of Diabetes and Prediabetes

\begin{tabular}{llll}
\hline & HBA1C $(\%)$ & $\begin{array}{l}\text { Fasting Blood } \\
\text { Glucose }(\mathrm{mg} / \mathrm{dl})\end{array}$ & $\begin{array}{l}\text { Plasma Glucose 2 Hours } \\
\text { After TTGO }(\mathrm{mg} / \mathrm{dl})\end{array}$ \\
\hline Diabetes & $\geq 6,5 \%$ & $\geq 126$ & $\geq 200$ \\
\hline Prediabetes & $5,7-6,4$ & $100-125$ & $140-190$ \\
\hline Normal & $<5,7$ & $<100$ & $>140$ \\
\hline
\end{tabular}

Diabetes Management Target

\begin{tabular}{ll}
\hline \multicolumn{1}{c}{ Parameter } & \multicolumn{1}{c}{ Target } \\
\hline BMI $\left(\mathrm{kg} / \mathrm{M}^{2}\right)$ & $18,5-<23^{*}$ \\
\hline Sistolic $(\mathrm{mmHg})$ & $<140$ \\
\hline Diastolic $(\mathrm{mmHg})$ & $<90$ \\
\hline Capillary pre prandial blood glucose $(\mathrm{mg} / \mathrm{dl})$ & $80-130^{* *}$ \\
\hline Capilarry post pandrial blood glucose $(\mathrm{mg} / \mathrm{dl})$ & $<180^{* *}$ \\
\hline HBA1c & $<7$ \\
\hline Cholesterol LDL $(\mathrm{mg} / \mathrm{dl})$ & $<100(<70$ bila risiko KV tinggi) \\
\hline Triglycerides $(\mathrm{mg} / \mathrm{dl})$ & $<150$ \\
\hline${ }^{*}$ The Asia Pasific Perpective Redefining Obesity and lts Treatment, 2000 & \\
${ }^{*}$ Standards of Mendical Care in Diabetes, ADA 2015 &
\end{tabular}

Complication

Complicationof Diabetes Mellitus that are often found are stroke, heart disease, neuropathy (nerve damage). Kidney failure, and diabetc foot which can manifest as ulcers, infections and gangrene, managing requires a long and continous time. This is done to control blood glucose levels so that diabetes does not develop into other disease.

Diabetes Management

Diabetes management include four pillars :

Pillar 1. Knowledge of diabetes mellitus.

As a result of lifestyle and behavior patterns, especially diet and inadequate activities, procedures for taking medication, eating pattern, complications, and emergency signs need to be owned by the patients and family. Knowledge of independent blood glucose monitoring need t obe taught in hypoglicemia or hyperglicemia.

Pillar 2. A balance diet. 
A balance diet is succesful management of diabetes mellitus. Eating arrangement and physical activity carried out for 2-4 weeks. If these 2things are not enough to control blood glucose then the doctors will give drug therapy.

Pliiar 3. Actively moving.

Physical excercise is very important to do at least $3-4$ times a week, for 30 minutes.

Pillar 4. Follow your medication

Adhere to the schedule and procedures for taking medication.

\section{METHODE}

This study were used literature review froum journals publishe at 2015- -2019 with the key words : trend of dicabetes mellitus in Indonesia. This is observational descritptive analytic study.

\section{RESULTS AND DISCUSSION}

Rahmi Yosmar, a survey of diabetes mellitus risk for the people of Padang City, 2018 stated that of 348 respondents aged $40-74$ years using the CANRISK (the Canadian Diabetes Risk Questionnaire) questionnaire using a croos sectional survey methode with perspective data collection. The results showed that $57.7 \%$ of respondents included in the high risk category, $34.5 \%$ moderate risk and $7.7 \%$ low risk of DM disease. Risk factors that have an influence on DM are gender, age, BMl, waist circumference, history of hypertension, history of high blood sugar, positive family hisroty of diabetes, and education level. While the risk factors that do not affect diabetes mellitus are physical activity, consumption of fruits/vegetables every day and ethinc parents/

The results of Riskesdas 2018 about diabetes are as folows :

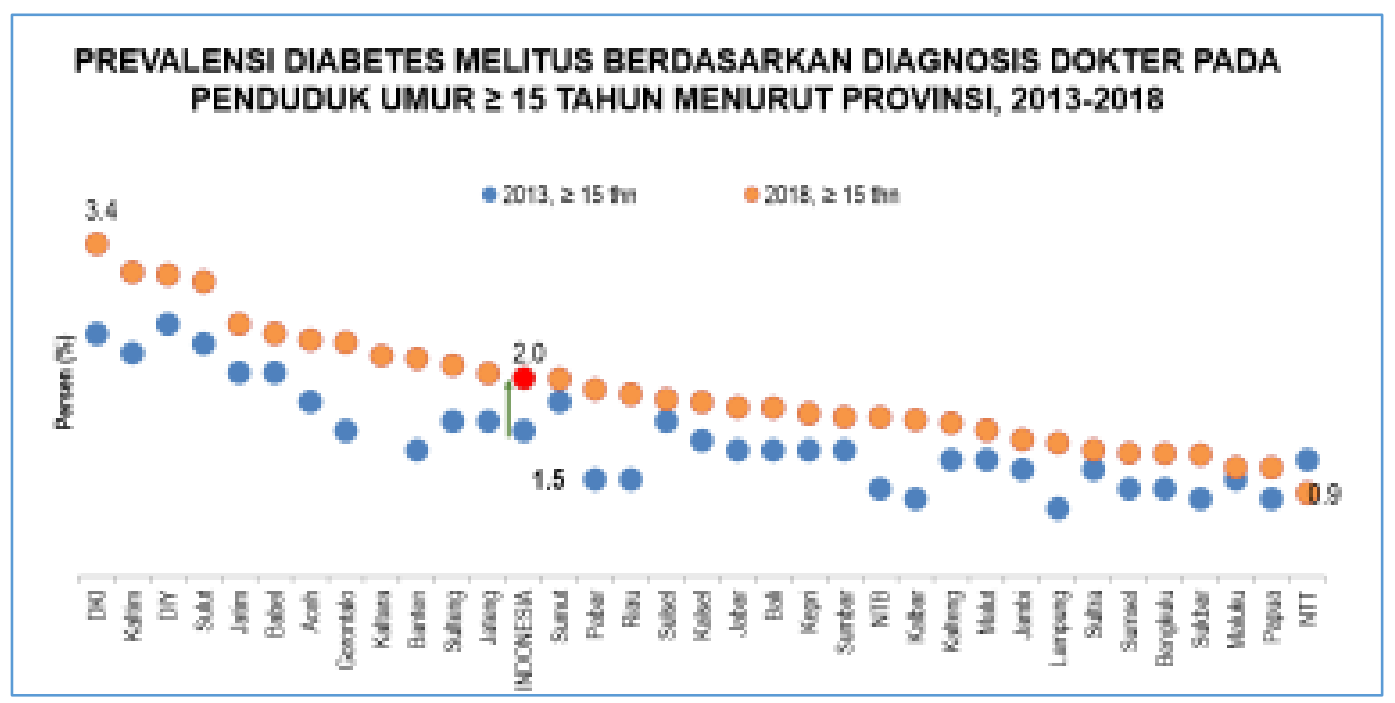

Source : Riskesdas, 2018

From the graphic above it is known that there are tendency of increasing the prevalence of diabetes mellitus at age above 15 years old in 2013 and 2018. 
Diabetes mellitus is a chronic disease that needs serious treatment, one ogf planning of them is through optimal diabetes controlling behavior planing. The implication of this study is a needed of a continous diabetes controling program for people with diabetes.

According to the data from WHO and Interneational Diabetes Federation (IDF), the problems of diabets in Indonesia has some same and differences characteristics with the problem of DM in the world. The same problems are (1) the incresing prevalence, (2) bad achievement of glicemic control, and (3) big cost for caring.

Based on study conduct by Prabaningrum, Kusumawati and Nugroho (2014) stated that urban lifestyle has bring negative impact to the changing of diaetary changes such as salty foods, preserved foods, snack consumption and fast food consumption, high consumption of instant noodle, the use of seasoning and lack of physical activity as a result of technological advances, one of which is the delivery order icon, either food or other needs, making people reluctant to travel or move. Lifestyle that is influenced by socioeconomic changes and apetite can results in people's eating patterns that tend to keep the concepts of balances diet so that it has a negative impact on health and nutrition.

Results study of Engkartini is 2015 showed that diabetes mellitus end to increase at average of $3.8 \%$. patients with type two diabetes mellitus are mostly female and aged over 45 years. Different test results showed differences in sex, age, and residence with a value $p<0.05$. hypertension and cholesterol factors have the same proprtions $(p>0.05)$.

Ariesda's study in 2018 found that the trend pf type 2 diabetes mellitus is age $\geq 46$ years, female, and do not have a history of hypertension. The prevalence and inceidents of events in changes of type 2 diabetes mellitus occurs annually, and their distribution is described usiang a spatial analysis of GIS.

Based on the results of study showedthat people with type 2 DM are more common in women. According to Sletzer and Bare (2013), physically women has the oppoturnity to increase body mas index that is greater than men, add to this the results of hormonal processes such as premenstrula syndrome and post menopouse. Increasing the hormone estrogen can reduce sensitivity to the action of insulin in the muscles and liver. Increased age is also a risk factor for diabetes. This is in the accordance with the he theory which states that the increasing age of person, the blood circulation towards the peripheral area decreases. Another possibility is because the ody's tissue cells are not sensitive or resistant to insulin due to aging. Increased incidence of type 2 DM associated with control of the 4 pillars that some patients do not know about diabetes mellitus education, poor food management, exercise 3 times a week with a frequency of $>30$ minutes, and most people who are not adherent to treatment (Son and Berawi, 2015). 


\section{PROPORSI OBESITAS SENTRAL PADA DEWASA $\geq 15$ TAHUN, 2018}

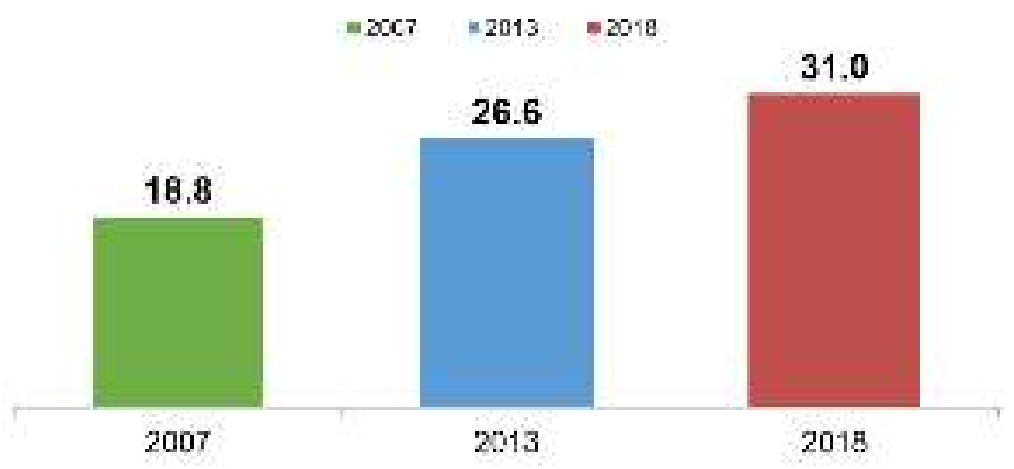

(Source : Riskesdas, 2018)

The proportion of obesity wuth an indicator of a woman's belly circumference of $80 \mathrm{~cm}$ and behavior of a man of $90 \mathrm{~cm}$ found a rising trend from 2007 to 2018 .

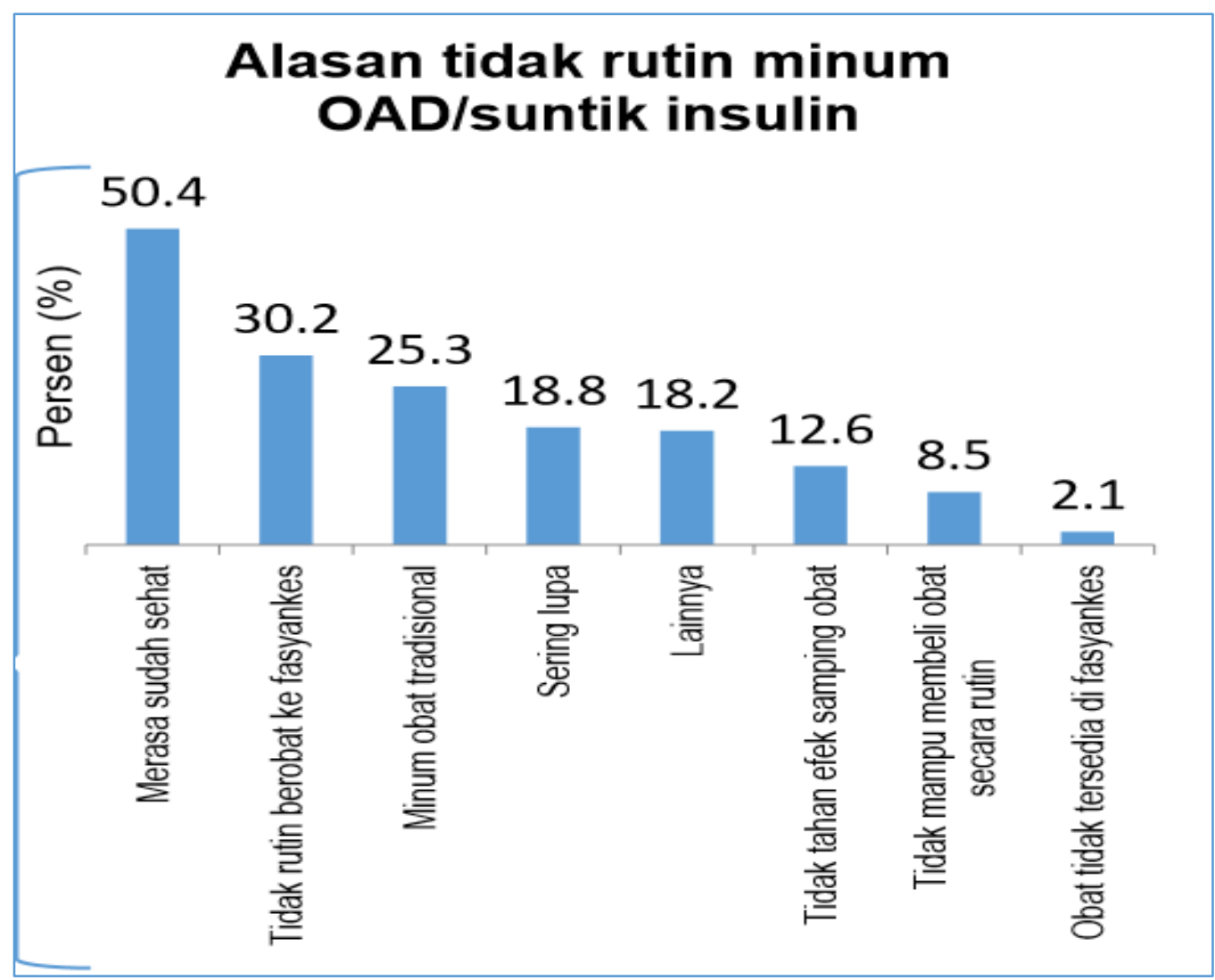

(Source : Riskedas 2018)

According to the picture, we see that the reason of people with diabetes didn't take their medicine routinely is because they already feel healthy and because they didn't visiting the health care routinely. 
The increasing prevalence of type 2 diabetes is correlate significantly with the controlling of the forth pillar which some patients has no idea about education of diabetes mellitus, do not have good eating arrangements, do not do exercise for more than 3 times a week with frequency of more than 30 minutes and most of people with diabetes are not obey the medication (Putra and Berawi, 2015).

The management of therapy that is not optimal also triggers the high complications of diabetes. Due to the community's lack of active participation in scheduled programs (PROLANIS) and lack of adherenceto type 2 diabetes mellitus treatment. This can be caused by several factors including the community not taking drugs on time or regularly checking blood glucose, not maintaining their diet, delaying their schedule routine control to Puskesmas or health services (Fathirohman, Fadhilah and Kunci, 2016). The tendency of increasing diabetes risk factors and the occurence of complications increase every year in diabetics. In addition to showing less than optimal program implementation, effective immediate action is needed to deal with this phenomenon, such as policy making that can maximize the performance of program implementers. This is consistent with efforts to achieve the SDGs indicator. National diabetes policy making and developing policies to promote and support a healthy lifestyle.

\section{CONCLUTION AND RECOMMENDATION}

Data from results and discussion have an upward trend in the coming year. There are several groups at risk including : increased age, female sex, heredity, ineffective glycemic control, obesity, activity, excessive carbohydrate consumption and irregularities in treatment and not using health care facilities for treatment.

Diabetes is a mentabolic disease that can cause comlications and this condition greatly affects the quality of life of people with diabetes. Diabetes can be controlled by diet arrangement, exercise and using anti diabetic drugs (OAD) properly and correctly in accordance with the expected target. Treatment of diabetes is spesific and individual. Modification of a healhty and clean lifestyle (PHBS) with a balance menu is needed in regulating the number of calorie and nutritional needs needed by diabetics. Diabetes is very influential in the quality of life and increased health costs.

Suggestions form researchers are that community plays an active rolein programs such as PROLANIS to prevent complications, health care providers can screen patients with type 2 diabetes, patients with DM complications, or patients with hypertentsion and DM to improve quality of life and reduce the incidence and new cases, especially type $2 \mathrm{DM}$. The next researcher is expected to study more detail to find out the factors contributing to the highest incidence.

The role of all parties both society and goverment is even more active in efforts to prevent diabets, especially in prevention efforts since this disease id chronic and will be carried for life. In addition to the community, health care teams such as physicians, nursesm and dietician play an important role and prevention and treatment of diabetes. Patients and families also has an important role to plaay because diabetes melitus requires ongoing care and ongoing patient self management education and support to prevent acute complication and reduce the risk of long term complications. 


\section{REFERENCE}

Konsensus Pengelolaan dan Pencegahan Diabetes Melitus Tipe 2 di Indonesia 2011. Jakarta : PB Perkeni ; 2011

PERKENI. (2015). Konsensus Pengelolaan dan Pencegahan Diabetes Melitus Tipe 2 di Indonesia. 2015, (DM), 1-58.

Putra, I. W. A., \& Berawi, K. (2015). Empat Pilar Penatalaksanaan Pasien Diabetes Mellitus Tipe 2. Jurnal Majority, 4(9), 8-12.

Prabaningrum, R. (2014). Hubungan Antara Perilaku Pengendalian Hipertensi Dengan Keberhasilan Penurunan Tekanan Darah Pada Kejadian Hipertensi Esensial Di Puskesmas Kratonan Surakarta, $34-54$.

Dinas Kesehatan Provinsi Jatim. 2013. Profil Kesehatan Provinsi Jawa Timur Tahun 2013. (Online).

International Diabetes Federation. (2015). IDF Diabetes Atlas. International Diabetes Federation. https://doi.org/10.1289/image.ehp.v119.i03

Kautzky-Willer, A., Harreiter, J., \& Pacini, G. (2016). Sex and gender differences in risk, pathophysiology and complications of type 2 diabetes mellitus. Endocrine Reviews, 37(3), 278316. https://doi.org/10.1210/er.2015-1137.

Notoatmodjo, S. 2007. Promosi Kesehatan dan Ilmu Perilaku. Jakarta: Rineka Cipta.

Notoatmodjo, S. 2010. Metodologi Penelitian Kesehatan. Jakarta: PT.Rineka Cipta.

Nursalam. 2013, .Konsep Dan Penerapan Metodologi Penelitian IImu Keperawatan, Edisi 2. Jakarta: Salemba Medika.

RISKESDAS. 2013. Laporan Hasil Riset Kesehatan Dasar. Jakarta: Badan Penelitian dan Pengembangan Kesehatan.

Setiadi. 2013. Konsep Dan Penulisan Riset Keperawatan. Yogyakarta: Graha IImu.

World Health Organization. (2016). Global Report on Diabetes. Isbn, 978, 88. https://doi.org/ISBN 9789241565257. 